\title{
Effects of Rate and Time of Application of Poultry Litter on Hoplolaimus columbus on Cotton
}

\author{
S. R. Koenning, Department of Plant Pathology, K. L. Edmisten, Department of Crop Science, K. R. Barker, \\ Department of Plant Pathology, D. T. Bowman, Department of Crop Science, College of Agriculture and Life \\ Sciences, North Carolina State University, Raleigh 27695; and D. E. Morrison, North Carolina Cooperative Exten- \\ sion Service, Laurinburg 28352
}

\begin{abstract}
Koenning, S. R., Edmisten, K. L., Barker, K. R., Bowman, D. T., and Morrison, D. E. 2003. Effects of rate and time of application of poultry litter on Hoplolaimus columbus on cotton. Plant Dis. 87:1244-1249.

Field experiments were conducted to evaluate the effect of soil-incorporated poultry litter on the population dynamics of Hoplolaimus columbus and cotton lint yield. Rates of poultry litter applied varied from 0.0 to 27.0 t/ha and were applied in December, February, or March. Time of application did not influence population densities of this nematode or cotton yield. The rate of poultry litter applied was negatively related to the population density of $H$. columbus at midseason, but not at other sampling dates. The lower midseason levels of this nematode corresponded with increases in cotton lint yield in all experiments. Cotton yield increases generally were linear with respect to the rate of litter applied, although the highest rates of litter applied did not always result in the greatest cotton yield. Poultry litter can be used effectively to supply nutrients to the crop and suppress damaging levels of $H$. columbus. Optimal rates of litter application were from 6.0 to $13.4 \mathrm{t} / \mathrm{ha}$. Application of poultry litter at these rates, however, may exceed nutrient levels required for best management practices.
\end{abstract}

Additional keywords: Columbia lance nematode, Gossypium hirsutum, management, manure, organic amendments, population dynamics, sustainable agriculture

The current distribution of the Columbia lance nematode, Hoplolaimus columbus Sher, in the United States includes Alabama, Georgia, North Carolina, and South Carolina (13). This nematode is a pathogen of cotton (Gossypium hirsutum), corn (Zea mays), and soybean (Glycine max), especially in sandy soil $(14,18,19)$. Nematode management in cotton is largely dependent on nematicides (26). Aldicarb or 1,3-dichloropropene are effective in preventing cotton-yield suppression by $H$. columbus $(16,17,25)$. The use of chemical nematicides, however, is increasingly under scrutiny by the public and government agencies (27). Furthermore, the cost of

Corresponding author: S. R. Koenning

E-mail: stephen_koenning@ncsu.edu

The research reported in this publication was funded, in part, by the North Carolina Agriculture and Life Sciences Experiment Station. The use of trade names does not imply an endorsement by the North Carolina Agricultural Research Service of the products named nor criticisms of similar ones not mentioned. Additional support was provided by Cotton Incorporated, project number 95$152 \mathrm{NC}$ and the Southern Region SARE/ACE program number LS94-60.

Accepted for publication 19 May 2003.

Publication no. D-2003-0721-04R

(C) 2003 The American Phytopathological Society nematicides can add an additional $\$ 37.00$ to $\$ 160.00$ per hectare to production costs, and there is a need to produce crops more economically in order to compete in the world market.

Tactics for management of Columbia lance nematode are limited. Rotation generally is not an option in fields infested with $H$. columbus because of its wide host range (7). Peanut (Arachis hypogaea) and tobacco (Nicotiana tabacum) can be used in rotation with host crops, but the hectarage of these crops is small relative to cotton. Cultural practices, including the use of winter wheat or rye cover crops, early cotton-root destruction, and planting date, had no impact on population densities of $H$. columbus $(5,12)$. Subsoiling in soil with a hardpan increased cotton and soybean yield when $H$. columbus was present, but many farmers have adopted reduced tillage practices that may eliminate subsoiling $(9,25)$. Resistance to $H$. columbus has not been identified in cotton or soybean, although some cotton cultivars are relatively tolerant to this nematode $(4,8)$. The recent rapid expansion in numbers of cotton cultivars, because of the deployment of transgenic insect- and herbicideresistant traits, has resulted in the use of cultivars with limited field data on nematode tolerance or resistance.

The need for alternatives to nematicides has stimulated research focusing on sustainable tactics for management of plant-parasitic nematodes $(1,15)$. Some research has focused on the utilization of animal and industrial waste products for control of nematodes. The addition of nitrogenous soil amendments results in the formation of ammonia that has nematicidal properties (23). More recently, a range of organic amendments, including chicken litter or other animal wastes, have provided considerable protection for plants against plant-parasitic nematodes $(10,21,22)$. Animal manure impacts communities of soil microorganisms and may stimulate organisms antagonistic to nematodes $(11,20,22,24)$. Chicken litter and manure have nematicidal or nematistatic properties $(10,21)$.

North Carolina is a leading state in poultry production. This industry generates enormous quantities of wastes that require environmentally acceptable means of disposal (3). These materials (manure or litter) generally are applied to agricultural land. An estimated 1.27 million t of poultry waste with 37,44 , and 25 thousand $t$ of nitrogen, phosphate, and potash, respectively, are produced annually in North Carolina. By increasing the efficiency of alternative nutrient sources, the nutritional needs of a crop can be met with fewer offfarm inputs, resulting in enhanced profitability (6). Mineralization is required before plant-available $\mathrm{N}$ is released; therefore, the use of these waste products can provide a source of slow-release $\mathrm{N}$ in soil, which may potentially limit groundwater contamination in soil most subject to leaching.

Additional tactics for management of $H$. columbus are needed. The use of biologically active waste products for management of plant-parasitic nematodes is an attractive alternative to chemical nematicides. Application of poultry litter and other biological wastes to agricultural land have the potential to decrease certain pest problems and minimize air and water pollution by these materials (6). The objectives of this research were to quantify the impact of time and rate of application of poultry litter on the population dynamics of $H$. columbus and subsequent cotton yield.

\section{MATERIALS AND METHODS}

All experiments were conducted between 1993 and 1996 in farmer fields 
naturally infested with the Columbia lance nematode. Two experiments were conducted in 1993-94 to determine the effects of date of litter application on population densities of Columbia lance nematode and cotton yields. The treatment design was a 3-by-4 factorial experiment with three dates of application (December, February, and late March) and four rates of poultry litter $(0,6.7,13.4$, and $20.1 \mathrm{t} / \mathrm{ha})$ at two locations. Plots were arranged in a randomized complete block design with six replicates at each location. One location was in Scotland County, NC on a Marlboro sandy loam (67\% sand, $20 \%$ silt, $13 \%$ clay), $\mathrm{pH} 6.0$, with organic matter less than $1 \%$. The other location was in Hoke County, NC on a Norfolk sandy loam $(67 \%$ sand, $14 \%$ silt, and $19 \%$ clay), $\mathrm{pH} 6.1$, with organic matter less than $1 \%$. The second set of experiments, conducted at two locations in Scotland County NC, was initiated in 1994 and 1995. These experiments were also 3-by-4 factorials, but were arranged in a split-plot design with whole plots as date of application (December, February, and late March) and subplots as rates of poultry litter $(0.0,9.0$, 18.0, and $27.0 \mathrm{t} / \mathrm{ha}$ ) with six replicates. The Gibson site, used in 1994-95, was a Marlboro loamy sand (67\% sand, $31 \%$ silt, $2 \%$ clay), $\mathrm{pH} 6.1$, with organic matter less than $1 \%$. The soil type at the Dozier site used in 1995-96 was a Wagram sand (88\% sand, $10 \%$ silt, and $2 \%$ clay), pH 5.7, with organic matter less than $1 \%$.

All plots consisted of four rows $6.1 \mathrm{~m}$ long with $0.96-\mathrm{m}$ row spacing and 3.0-m alleys between plots. Plots were measured in the fall of each year when the first application of poultry litter was made. The plot limits of the experiments were marked by burying metal at the corners, which were located with a metal detector prior to subsequent poultry litter applications and after planting. Cotton cv. Deltapine 50 was used in the first set of experiments in 1994, and cv. Stoneville 474 in 1995 and 1996. Plots were planted in May of each year by the grower with the application of aldicarb at $0.5 \mathrm{~kg}$ a.i./ha in furrow for insect control. Poultry litter was obtained from local sources and covered with a tarp to maintain moisture content and minimize changes in nutrient content over time. The nutrient content of the litter was analyzed by the North Carolina Department of Agri- culture and Consumer Services (Table 1). Applications of poultry litter were made to selected plots in December, February, or March each winter, and was incorporated with a disk within 3 days after application. Plots that did not receive poultry litter were fertilized according to soil test recommendations for North Carolina, and plots receiving litter did not receive supplemental fertilizer. Alleys between plots were cut by hand 2 weeks prior to harvest. Plots were harvested with a commercial cotton picker. Lint yield was determined by ginning subsamples of seed cotton taken from the first two replications.

Samples for nematode assays were collected prior to the first application of poultry litter in December $(\mathrm{Pt})$, at planting in May (Pi), at midseason (July or August; $\mathrm{Pm}$ ), and at cotton harvest (October; Pf). An additional sample was taken in the experiments from 1993-94 after the last application of litter in late March or early April (spring; Pa). Each soil sample con-

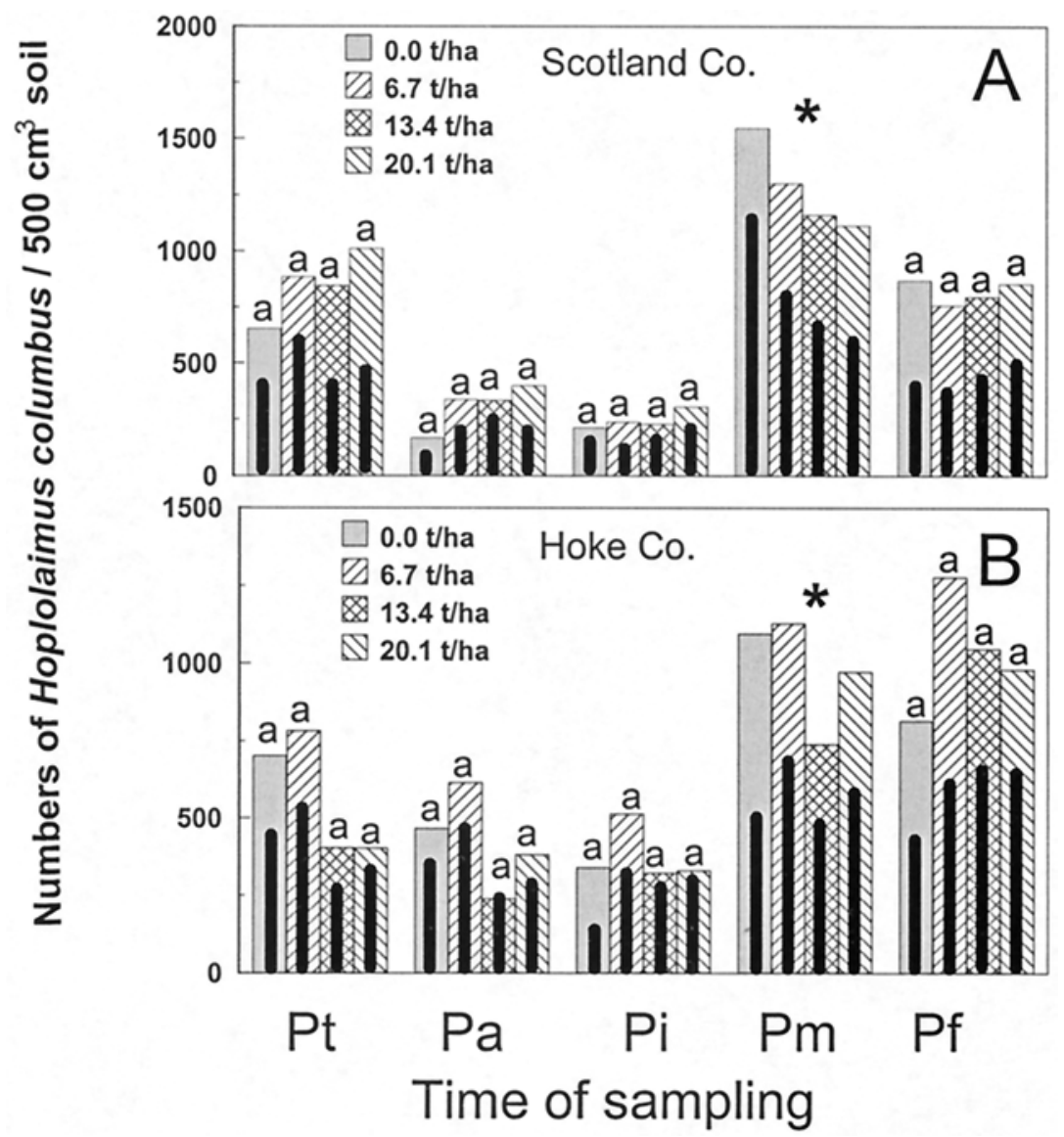

Fig. 1. Population densities of Hoplolaimus columbus per $500 \mathrm{~cm}^{3}$ of soil at five sampling dates $($ December $=\mathrm{Pt}$, April $=\mathrm{Pa}$, May $=\mathrm{Pi}$, July $=\mathrm{Pm}$, and cotton harvest in October $=\mathrm{Pf})$ in response to application of poultry litter at three dates (December, February, and March; not significant at $P \leq$ $0.05)$ and at four rates $(0.0,6.7,14.0$ or $20.1 \mathrm{t} / \mathrm{ha})$ from 1993 to 1994 at two locations in North Carolina. A, Poultry litter at the Scotland County location was not significant for $\mathrm{Pt}, \mathrm{Pa}$, and $\mathrm{Pf}(P \leq$ $0.05)$; cubic $(P \leq 0.01)$ for the at-planting sample $(\mathrm{Pi})$; and linear $(P \leq 0.05)$ at midseason $(\mathrm{Pm})$. B, Poultry litter at the Hoke County site was not significant at $\mathrm{Pt}, \mathrm{Pa}$, and $\mathrm{Pf}(P \leq 0.05)$; cubic $(P \leq 0.01)$ for the at-planting sample $(\mathrm{Pi})$; and linear $(P \leq 0.05)$ at midseason $(\mathrm{Pm})$. Each bar is the mean of 18 observations. Lines within bars are the standard deviation of the mean. Means within a sampling time followed by the same letter do not differ; * denotes significant linear effect of rate of litter on population densities within a sampling time (orthogonal contrasts, $P \leq 0.05$ ).

Table 1. Nutrient composition of poultry litter used in four experiments for management of Hoplolaimus columbus in North Carolina from 1993 to 1996

\begin{tabular}{|c|c|c|c|c|c|c|c|c|c|c|c|c|c|}
\hline \multirow[b]{3}{*}{ Location, year } & \multicolumn{13}{|c|}{ Nutrient composition $^{a}$} \\
\hline & \multicolumn{7}{|c|}{ Percent } & \multicolumn{6}{|c|}{ Parts per million } \\
\hline & DM & $\mathbf{N}$ & $\mathbf{P}$ & $\mathbf{K}$ & $\mathbf{C a}$ & Mg & $\mathbf{S}$ & $\mathbf{F e}$ & Mn & Zn & $\mathbf{C u}$ & B & $\mathrm{Na}$ \\
\hline Scotland County 1993-94 & 81.4 & 4.80 & 1.28 & 2.26 & 2.77 & 0.59 & 0.58 & 126 & 631 & 674 & 457 & 31.9 & 0.76 \\
\hline Hoke County 1993-94 & 66.1 & 3.00 & 2.33 & 2.21 & 3.45 & 0.79 & 0.47 & 1,822 & 635 & 540 & 497 & 20.1 & 0.55 \\
\hline Gibson 1994-95 & 68.6 & 3.68 & 1.52 & 2.74 & 2.73 & 0.60 & 0.70 & 692 & 554 & 631 & 335 & 42.7 & 0.87 \\
\hline Dozier 1995-96 & 72.2 & 3.65 & 1.74 & 2.30 & 2.82 & 0.56 & 0.60 & 680 & 553 & 668 & 478 & 36.8 & 0.85 \\
\hline
\end{tabular}

a Analysis provided by the Plant, Waste Solution Section Agronomic Division of The North Carolina Department of Agriculture and Consumer Services; $\mathrm{DM}=$ percentage of dry matter. 
sisted of 8 to 102.5 -cm-diameter cores taken to a depth of $15 \mathrm{~cm}$ and composited. A $500-\mathrm{cm}^{3}$ subsample was processed by elutriation and centrifugation, and roots were placed in a mist extractor for 5 days to extract vermiform stages (2).

Analysis of variance (ANOVA) for the appropriate statistical design was conducted on the data with PC/SAS software
(SAS Institute, Cary, NC). Locations (or years) for the field tests were considered to be random effects, whereas date of application and rate of litter application were treated as fixed effects. Significant data for each field location are presented separately because locations (and years) were significantly different. Pearson correlation coefficients were used on data com-

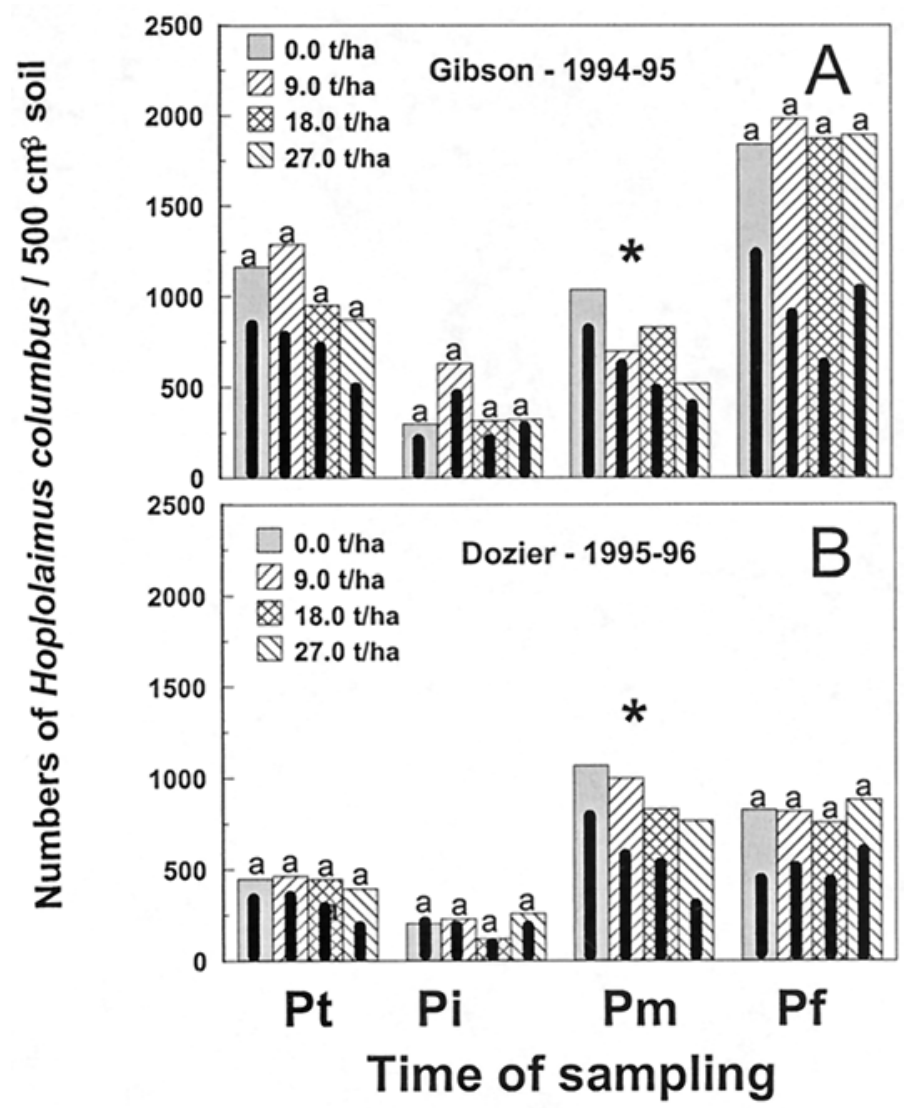

Fig. 2. Numbers of Hoplolaimus columbus per $500 \mathrm{~cm}^{3}$ of soil at four sampling dates (December $=$ $\mathrm{Pt}$, May $=\mathrm{Pi}$, July $=\mathrm{Pm}$, and cotton harvest in October $=\mathrm{Pf}$ ) in response to application of poultry litter at three dates (December, February, and March; not significant at $P \leq 0.05$ ) and at four rates $(0.0,9.0,18.0$, or $27.0 \mathrm{t} / \mathrm{ha})$ at two locations. A, The Gibson site, 1994-95, and B, the Dozier site, 1995-96. Each bar is the mean of 18 observations. Lines within bars are the standard deviation of the mean. Means within a sampling time followed by the same letter do not differ, although there was a significant cubic effect (orthogonal polynomial contrasts, $P \leq 0.01$ ) of rate of poultry litter at both locations for Pi. Asterisk (*) denotes significant linear effect of rate of litter on population densities at midseason (orthogonal polynomial contrasts, $P \leq 0.05$ ).

bined over years and locations to evaluate the effects of litter on cotton yield and nematode population densities. Orthogonal polynomial contrasts for equally spaced treatment levels were used to evaluate the effects of rate of poultry litter. Regression analyses were used to develop linear or quadratic models relating nematode numbers and rate of poultry litter application to cotton lint yield. Nematode numbers were transformed $\left(\log _{10}[x+1]\right)$ to normalize variances. Untransformed data are presented in tables for clarity.

\section{RESULTS \\ Impact of poultry litter application on} H. columbus. The rate of poultry litter applied did not affect population densities of $H$. columbus following the last application of poultry litter in March $(\mathrm{Pa})$ or at cotton planting $(\mathrm{Pi})$ in 1994 at either site (Fig. 1). Similarly, at planting, numbers of Columbia lance nematode $(\mathrm{Pi})$ were not affected $(P \leq 0.05)$ by the rate of poultry litter at either location in 1995 or 1996 (Fig. 2). There was a cubic effect of rate of litter application (orthogonal polynomial contrasts; cubic, $P \leq 0.01$ ) on post-application populations $(\mathrm{Pa})$ in 1994 and on population densities of $H$. columbus at planting $(\mathrm{Pi})$ in the second series of experiments (Figs. 1 and 2). Midseason numbers of $H$. columbus $(\mathrm{Pm})$ were negatively related (orthogonal polynomial contrasts, $P \leq$ 0.01 ) to the application rate of poultry litter at the Scotland County site in 1994 (Fig. 1). Only the 13.4- and 20.1-t/ha rates resulted in significant suppression of $H$. columbus numbers at midseason $(\mathrm{Pm})$ at the Hoke County site (contrast 0 versus 13.4 and $20.1 \mathrm{t} / \mathrm{ha}, P=0.03)$. In the second series of experiments initiated in 1994 and 1995, population densities of $H$. columbus at midseason $(\mathrm{Pm})$ were negatively related (orthogonal polynomial contrasts, $P \leq$ $0.01)$ to the rate of poultry litter applied at both locations (Fig. 2). Numbers of $H$. columbus at cotton harvest $(\mathrm{Pf})$ were not influenced by the rate of poultry litter applied in either series of experiments. In an analysis across all locations, the

Table 2. Partial analysis of variance of experiments combined over locations performed in 1993-94 for cotton lint yield and population densities of Hoplolaimus columbus per $500 \mathrm{~cm}^{3}$ of soil after litter application in April (Pa), at planting (Pi), midseason $(\mathrm{Pm})$, and cotton harvest (Pf)

\begin{tabular}{|c|c|c|c|c|c|c|}
\hline \multirow[b]{2}{*}{ Source } & \multirow[b]{2}{*}{ DF } & \multicolumn{5}{|c|}{$F$ value $^{\mathrm{a}}$} \\
\hline & & $\mathbf{P a}$ & $\mathbf{P i}$ & Pm & Pf & Yield \\
\hline Replication & 5 & 0.84 & 1.68 & 0.50 & 0.70 & 0.32 \\
\hline Date of application & 2 & 0.12 & 1.66 & 0.70 & 0.32 & 0.52 \\
\hline Rate of litter & 3 & 2.11 & 0.96 & 1.23 & 0.80 & $3.89^{*}$ \\
\hline Linear & 1 & 0.78 & 0.70 & $3.29 *$ & 0.64 & $10.02 * *$ \\
\hline Quadratic & 1 & 0.15 & 0.25 & 0.15 & 1.33 & 0.07 \\
\hline Cubic & 1 & $4.79 *$ & 1.94 & 0.65 & 0.49 & 1.30 \\
\hline Location & 1 & 2.07 & 0.44 & $9.89 * *$ & 0.34 & $120^{* *}$ \\
\hline Date $\times$ litter & 6 & 0.72 & 0.56 & 0.22 & 0.58 & 0.11 \\
\hline Date $\times$ location & 2 & 0.30 & 1.15 & 0.12 & 0.76 & 0.38 \\
\hline Litter $\times$ location & 3 & 2.54 & 1.22 & 0.27 & 1.31 & $3.14^{*}$ \\
\hline Date $\times$ litter $\times$ location & 6 & 0.30 & 0.25 & 0.80 & 0.48 & 0.53 \\
\hline
\end{tabular}

a Nematode population densities were on $\log$ transformed data $\left(\log _{10}[x+1]\right)$ for analysis. Values followed by $*$ are significant at $P \leq 0.05$, and values followed by $* *$ are statistically significant at $P \leq 0.01$. 
population densities of $H$. columbus at midseason $(\mathrm{Pm})$ were negatively correlated to the amount of litter applied $(r=-0.16, P$ $=0.007$ ), but population densities at other sampling dates were not correlated. The date of application did not influence population densities of $H$. columbus in either set of experiments at any sampling date (Tables 2 and 3).

Influence of poultry litter application on cotton yield. Cotton lint yield at the Hoke County site was much lower than at the Scotland County site in 1994 (Fig. 3). Cotton lint yield was positively correlated with the amount of litter applied $(r=0.16$, $P=0.006)$. The rate of poultry litter applied resulted in a linear increase (orthogonal polynomial contrasts, $P \leq 0.01)$ in cotton lint yield at the Scotland County site in 1994. Cotton lint yields best fit a quadratic model (orthogonal polynomial contrasts, $P=0.04$ ) with respect to the rate of poultry litter applied at the Hoke County site in 1994. Cotton lint increased up to the 13.4-t/ha rate at this site but decreased at the highest rate of litter applied (20.1-t/ha rate) compared with the $13.4-\mathrm{t} / \mathrm{ha}$ rate. Both quadratic and linear models (orthogonal polynomial contrasts; linear $P$ $=0.04$, quadratic $P=0.02$, ) described the relationship of rate of poultry litter applied at the Gibson site in 1995 (Fig. 4). Greatest yields at this location were with litter at 9.0 to 18.0 t/ha. In 1996, cotton lint yield increased (orthogonal polynomial contrasts, linear $P=0.02$ ) with increasing amounts of poultry litter applied at the Dozier site. Midseason numbers $(\mathrm{Pm})$ of $H$. columbus were not related to cotton lint yield in the first set of experiments conducted in 1994. However, populations of H. columbus $\mathrm{Pm}$ were negatively related to cotton lint yield at both sites in the splitplot experiments conducted from 1994 to 1996 (Gibson site: $Y=2033-320 X, R^{2}=$ $0.29, P \leq 0.01$; Dozier site: $Y=1506-$ 92.6X, $\left.R^{2}=0.06, P \leq 0.04\right)$. The application date of poultry litter had no effect $(P \leq$ 0.05 ) on cotton lint yield in any experiment conducted (Tables 2 and 3).

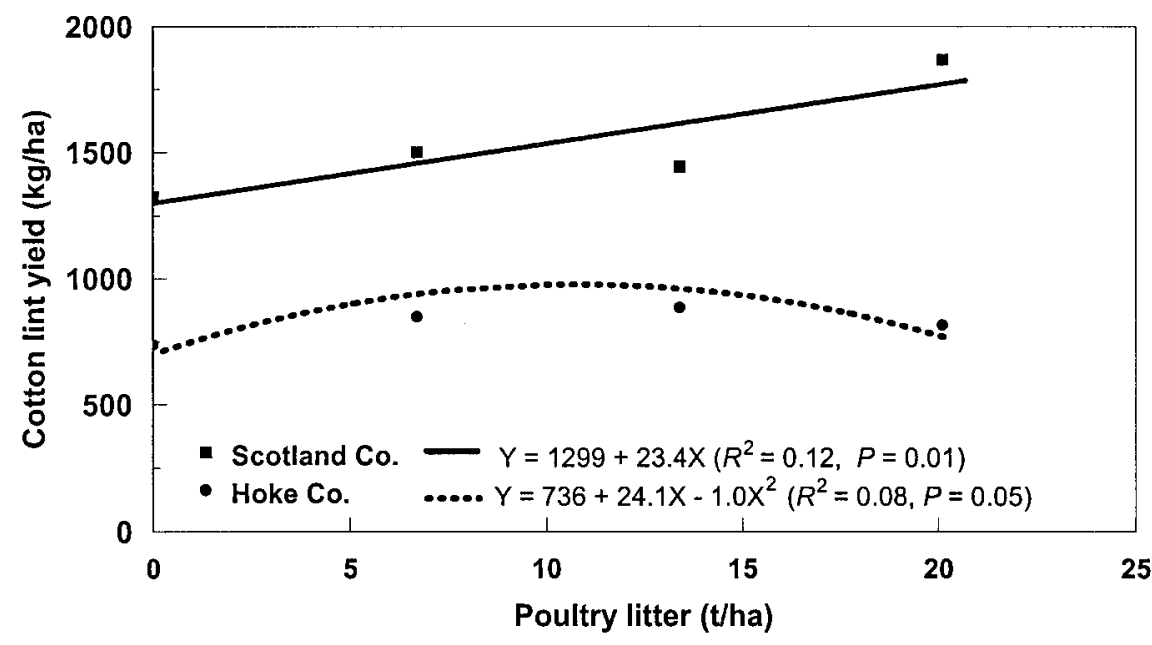

Fig. 3. Cotton lint yield ( $\mathrm{kg} / \mathrm{ha})$ in response to applications of different rates of poultry litter $(0.0$, 6.7, 14.0, or $20.1 \mathrm{t} / \mathrm{ha}$ ) in 1994 at two locations (Hoke and Scotland Counties) in North Carolina. Cotton lint yield increased linearly with increasing rates of poultry litter at the Scotland County site (orthogonal polynomial contrasts, $P=0.01$ ), and was best fit by a quadratic model (orthogonal polynomial contrasts, $P=0.04$ ) with respect to application rate of poultry litter at the Hoke County site. Each square or solid circle is the mean of 18 observations summed over application date and replication. Regression equations are based on analyses of all data.

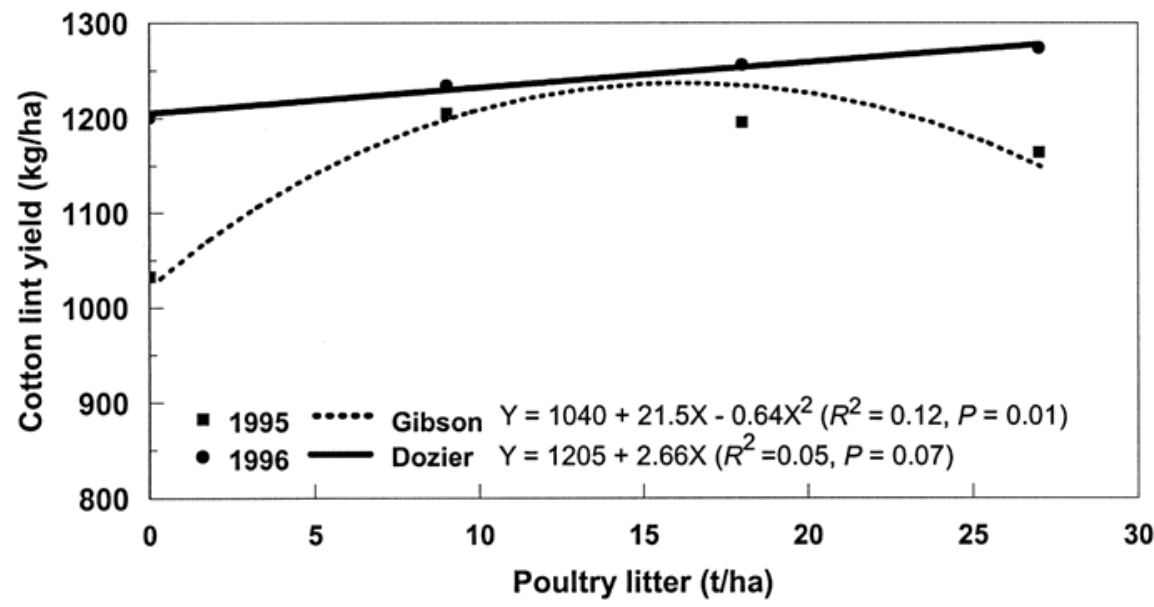

Fig. 4. Influence of poultry litter applications at different rates $(0.0,9.0,18.0$, or $27.0 \mathrm{t} / \mathrm{ha})$ on cotton lint yield (kg/ha) at two locations in Scotland County, NC for 1995 at the Gibson site and 1996 at the Dozier site. Poultry litter rate effected a linear increase in cotton yield at the Dozier site in 1996 (orthogonal polynomial contrasts, $P=0.02$ ), whereas the relationship at the Gibson site in 1995 was fit by both linear and quadratic models (orthogonal polynomial contrasts, linear, $P=0.04$; quadratic, $P=0.02)$. Each square or solid circle is the mean of 18 observations summed over application date and replication. Regression equations are based on analyses of all data.

Table 3. Partial analysis of variance of split-plot experiments combined over years performed in 1994 to 1996 for cotton lint yield (kg/ha) and population densities of Hoplolaimus columbus per $500 \mathrm{~cm}^{3}$ of soil at planting $(\mathrm{Pi})$, midseason $(\mathrm{Pm})$, and cotton harvest $(\mathrm{Pf})$

\begin{tabular}{|c|c|c|c|c|c|}
\hline \multirow[b]{2}{*}{ Source } & \multirow[b]{2}{*}{ DF } & \multicolumn{4}{|c|}{$F$ value $^{\text {a }}$} \\
\hline & & $\mathbf{P i}$ & Pm & Pf & Yield \\
\hline Replication (Rep) & 5 & 1.23 & 0.96 & 0.31 & 2.16 \\
\hline Date of application & 2 & 0.78 & 0.05 & 0.04 & 0.45 \\
\hline Rate of litter & 3 & $3.31 *$ & 1.64 & 0.13 & $3.90^{*}$ \\
\hline Linear & 1 & 0.19 & $3.73^{*}$ & 0.21 & $6.94 * *$ \\
\hline Quadratic & 1 & 0.54 & 0.02 & 0.01 & $4.29 *$ \\
\hline Cubic & 1 & $9.24 * *$ & 1.36 & 0.09 & 0.46 \\
\hline Year (location) & 1 & $8.25 * *$ & 3.00 & $71.7 * *$ & $11.0 * *$ \\
\hline Rep $\times$ date (whole plot error) & 10 & $2.31 *$ & $3.90 * *$ & 1.35 & 1.59 \\
\hline Date $\times$ litter & 6 & 0.73 & 0.24 & 0.38 & 0.32 \\
\hline Date $\times$ year & 2 & 0.10 & 0.67 & 0.75 & 0.29 \\
\hline Litter $\times$ year & 3 & 1.55 & 0.47 & 0.53 & 1.35 \\
\hline Date $\times$ litter $\times$ year & 6 & 0.77 & 0.18 & 0.82 & 0.45 \\
\hline
\end{tabular}

${ }^{a}$ Nematode population densities were on $\log$ transformed data $\left(\log _{10}[x+1]\right)$ for analysis. Values followed by $*$ are significant at $P \leq 0.05$, and values followed by $* *$ are statistically significant at $P \leq 0.01$. 


\section{DISCUSSION}

The negative linear response of midseason $H$. columbus population densities to the rate of application of poultry litter demonstrated that this organic amendment may be useful in management of this nematode in cotton. Although the reduction in numbers of $H$. columbus by poultry litter was statistically significant, the actual suppression of nematode population density was relatively small. The effect of litter was not significant unless the rate of litter application was considered via orthogonal polynomial contrasts or regression. Experimenters using only one rate of litter, especially a low rate, could conclude that litter did not suppress nematode numbers.

Final population densities of $H$. columbus were unaffected by litter application rates, although midseason numbers were. This response is similar to that often encountered with chemical nematicides, especially nonfumigant nematicides (2). The relatively small impact of poultry litter and the shortlived nature of the effect on Columbia lance nematode numbers indicates that the application of this soil amendment would only be sufficient for the current crop. This or other tactics would need to be used in subsequent years.

Cotton lint yield was improved with application of poultry litter at all locations in both years. The positive correlation of yield with litter application rates combined with the negative correlation of midseason numbers of Columbia lance nematode with rate of litter applied indicates that the two phenomena are related. In the first set of experiments, the negative relationship of midseason $H$. columbus numbers with cotton yield was not significant, whereas the relationship was significant in the second series of experiments. The split-plot design used in the second series of experiments probably was more effective in isolating spatial variation in nematode population densities than the randomized complete block design used in the first set of experiments, thus increasing precision. Quadratic responses of yield to the rate of poultry litter applied that occurred at the Hoke County site in 1994 and at the Dozier site in 1996 indicate that application of litter at high rates will not result in a further increase in cotton yield. Over fertilization may result in excessive vegetative growth that limits cotton yield potential. Cotton fruit that are set late in the season may fail to mature and divert photosynthate and minerals needed for lint production.

The optimum rate for application of litter for management of this nematode and increased lint yield appears to be between 9.0 and $13.4 \mathrm{t} / \mathrm{ha}$. Rates of litter greater than the 13.4-t/ha rate used in this research resulted in significantly higher yields than the 9.0 - to $13.4-\mathrm{t} /$ ha rate in only one instance. Although higher rates were more effective in suppressing $H$. columbus numbers, increases in cotton yield diminished with increasing rates of litter.

The absence of an effect on nematode populations due to application date was not anticipated. Other research on the addition of organic amendments to soil demonstrated that these amendments stimulate fungi antagonistic to plant-parasitic nematodes (24). Addition of organic amendments to soil stimulates microbial activity. Earlier application to soil, such as fall application versus spring application, should allow more time for the formation of nematicidal ammonia (23). Also, fall application would provide for a longer period for the ammonia to have a negative impact on nematode population densities and for microbial antagonists of nematodes to be active. However, greenhouse experiments with the southern root-knot nematode Meloidogyne incognita and poultry litter additions to soil also failed to quantify a specific impact of application date on reduction in the numbers of rootknot nematode (22).

Addition of chicken litter to soil in the fall or winter in this study may not have had the desired effect for several reasons. Low soil temperature during winter and early spring may inhibit the release of ammonia and probably minimizes microbial activity in soil. Second, H. columbus has a relatively high temperature optimum, and likely exists in a dormant or semidormant condition during winter (19). The decline in population levels of this nematode vary on a yearly basis in North Carolina, and likely are related to low soil temperatures (12). As a result of the large decline in numbers of this nematode over winter, it may be difficult to quantify the impact of soil amendments applied in winter or early spring on nematode densities. The highly significant cubic relationship of rate of litter application with numbers of H. columbus in early-spring samples $(\mathrm{Pa})$ in 1994 and in preplant samples $(\mathrm{Pi})$ in 1995-96 likely are a result of the clustered distribution of plant-parasitic nematodes in soil, but could be related to chemical or biological activity which stimulated or depressed nematode activity in a manner inconsistent with the rate of litter applied. Other researchers reported an increase in numbers of $M$. incognita shortly after addition of poultry litter to soil (22). Still, the impact of the expected negative linear effect of rate of litter addition to soil on $H$. columbus was not evident until midseason in this study.

Increasingly, pollution of ground and surface water with nutrients from agriculture is being regulated (Senate Bill 1217, 1996, NC; North Carolina General Statutes 143-214.1, 143-214.7, 143-215.3 [a] [1]; Eff. 1 August 1998). Current regulations for land application of poultry litter in North Carolina requires that only the amount needed for fertilization of the crop be applied in accordance with best management practices (BMP). The amount that may be applied is related to soil series, slope, whether the soil is eroded or noneroded, and the realistic yield expectation (RYE) for the crop in question. Based on BMP and the RYE for the soil used in this research, the amount of poultry litter that may be applied is approximately 6 to 9 $\mathrm{t} / \mathrm{ha}$. Thus, some suppression of Columbia lance nematode is to be expected at rates based on the RYE and BMP, but additional tactics may be needed for very susceptible cultivars or when the population density of this nematode exceeds the economic damage threshold. Also, a crop must be in place within 30 days of application; therefore, winter applications could be made only if a winter cover crop such as rye or wheat was planted. Potentially, the use of a cover crop would allow for the application of higher amounts of litter, which would permit rates suppressive to the nematode to be applied.

\section{ACKNOWLEDGMENTS}

We thank J. A. Phillips, K. M. Parker, C. H Echerd, E. Strong, D. R. Parrish, and J. R. Denton for assistance with all aspects of this research; cooperative extension agent $\mathrm{G}$. Warren and grower cooperators J. Boyles, P. Dozier, T. G. Gibson, and H. A. McLauren for providing land for the field experiments; and H. D. Shew and J. L. Imbriani for their review and helpful comments.

\section{LITERATURE CITED}

1. Barker, K. R., and Koenning, S. R. 1998. Developing sustainable systems for nematode management. Annu. Rev. Phytopathol. 36:165-205.

2. Barker, K. R., Townshend, J. F., Bird, G. W. Thomason, I. J., and Dickson, D. W. 1986. Determining nematode population responses to control agents. Pages 283-296 in: Methods for Evaluating Pesticides for Control of Plant Pathogens. K. D. Hickey, ed. American Phytopathological Society Press, St. Paul, MN.

3. Barker, J. C., and Zublena, J. P. 1995. Livestock manure nutrient assessment in North Carolina. Proc 7th Intl. Symp. Agric. Food Processing Wastes, ASAE Publ. 7-95, St. Joseph, MO.

4. Bowman, D. T., and Schmitt, D. P. 1994 Screening cotton for tolerance to Hoplolaimus columbus. Plant Dis. 78:695-697.

5. Davis, R. F., Baird, R. E., and McNeill, R. D. 2000. Efficacy of cotton root destruction and winter cover crops for suppression of Hoplolaimus columbus. Suppl. J. Nematol. 32:550555.

6. Edwards, D. R., and Daniel, T. C. 1992. Environmental impact of on-farm poultry waste disposal-a review. Biores. Technol. 41:9-33.

7. Fassuliotis, G. 1974. Host range of the Columbia lance nematode Hoplolaimus columbus. Plant Dis. Rep. 58:1000-1002.

8. Hill, A. S., May, O. L., and Mueller, J. D. 1994. Evaluation of tolerance to Meloidogyne incognita and Hoplolaimus columbus in cotton genotypes. (Abstr.) J. Nematol. 6:550.

9. Hussey, R. S. 1977. Effect of subsoiling and nematicides on Hoplolaimus columbus populations and cotton yield. J. Nematol. 9:83-86.

10. Kaplan, M., and Noe, J. P. 1993. Effects of chicken-excrement amendments on Meloidogyne arenaria. J. Nematol. 25:71-77.

11. Kaplan, M., Noe, J. P., and Hartel, P. G. 1992. The role of microbes associated with chicken 
litter in the suppression of Meloidogyne arenaria. J. Nematol. 24:522-527.

12. Koenning, S. R., Edmisten, K. L., Barker, K. R., and Morrison, D. E. 2003. Impact of cotton production systems on management of Hoplolaimus columbus. J. Nematol. 35:73-77.

13. Koenning, S. R., Overstreet, C., Noling, J. W., Donald, P. A., Becker, J. O., and Fortnum, B. A. 1999. Survey of crop losses in response to phytoparasitic nematodes in the United States for 1994. Suppl. J. Nematol. 31:587-618.

14. Lewis, S. A., and Smith, F. H. 1976. Host plant distribution and ecological associations of Hoplolaimus columbus. J. Nematol. 8:264270.

15. McSorley, R., and Poranzinska, D. L. 2001. Elements of sustainable agriculture. Nematropica 31:1-9.

16. Mueller, J. D., and Sullivan, M. J. 1988. Response of cotton to infection by Hoplolaimus columbus. Ann. Appl. Nematol. (J. Nematol. 20 Suppl.) 2:86-89.

17. Noe, J. P. 1990. Efficacy of fumigant nemati- cides to control Hoplolaimus columbus on cotton. Suppl. J. Nematol. 22:718-723.

18. Noe, J. P. 1993. Damage functions and population changes of Hoplolaimus columbus on cotton and soybean. J. Nematol 25:440445.

19. Nyczepir, A. P., and Lewis, S. A. 1979. Relative tolerance of selected soybean cultivars to Hoplolaimus columbus and possible effects of soil temperature. J. Nematol. 11:27-31.

20. Opperman, M. H., Wood, M., Harris, P. J., and Cherrett, C. P. 1993. Nematode and nitrate dynamics in soils treated with cattle slurry. Soil Biol. Biochem. 25:19-24.

21. Riegel, C., Fernandez, F. A., and Noe, J. P. 1996. Meloidogyne incognita infested soil amended with chicken litter. J. Nematol. 28:369-378.

22. Riegel, C., and Noe, J. P. 2000. Chicken litter soil amendment effects on soilborne microbes and Meloidogyne incognita on cotton. Plant Dis. 84:1275-1281.

23. Rodriguez-Kabana, R. 1986. Organic and inorganic amendments to soil as nematode suppressants. J. Nematol. 18:129-135

24. Rodriguez-Kabana, R., Morgan-Jones, G., and Chet, I. 1987. Biological control of nematodes: Soil amendments and microbial antagonists. Plant Soil 100:237-247.

25. Schmitt, D. P., and Bailey, J. E. 1990. Chemical control of Hoplolaimus columbus on cotton and soybean. Suppl. J. Nematol. 22:689694.

26. Starr, J. L. 1998. Cotton. Pages 359-380 in Plant and Nematode Interactions. Agron. Monogr. 36. K. R. Barker, G. A. Pederson, and G. L. Windham, eds. American Society of Agronomy, Crop Science Society of America, and Soil Science Society of America, Madison, WI.

27. Thomason, I. J. 1987. Challenges facing nematology: environmental risks with nematicides and the need for new approaches. Pages 469-476 in: Vistas on Nematology. J. A. Veech and D. W. Dickson, eds. Society of Nematologists, Hyattsville, MD. 